ESJ Social Sciences

\title{
Attitudes Toward COVID-19 Lockdown As A Risk Predictor In Panama
}

\author{
Ericka Matus \\ Jay Molino
}

Departmento de Biociencias y Salud Pública, Corregimiento de Ancón, Albrook, Paseo Diógenes de la Rosa, Panamá,Universidad Especializada de las Américas

Sistema Nacional de Investigación, SNI, SENACYT, Panamá

Lorena Matus

Department of Psicología, Universidad Iberoamericana, Santa Fe, Ciudad de México, México

Doi:10.19044/esj.2021.v17n15p1

Submitted: 03 February 2021

Accepted: 06 May 2021

Published: 31 May 2021
Copyright 2021 Author(s)

Under Creative Commons BY-NC-ND

4.0 OPEN ACCESS

Cite As:

Matus E., Molino J. \& Matus L. (2021). Attitudes Toward COVID-19 Lockdown As A Risk Predictor In Panama.

European Scientific Journal, ESJ, 17(15), 1. https://doi.org/10.19044/esj.2021.v17n15p1

\begin{abstract}
This document describes an investigation undertaken to examine attitudes towards lockdowns through COVID-19 as a psychosocial risk predictor in Panama. We conducted the study through a cross-sectional, prospective, and correlational approach. The study was constructed containing psychometric characteristics in the form of 36 Likert scale items to collect data. The instrument was sent to 233 participants via Google form between April 17 and April 30, 2020. The participants responded fully to the questionnaire. We analyzed the data by mean comparisons, correlation, and regression. There is a significant correlation between each of the studied factors and attitudes. The results indicate that women and people over the age of 51 have a positive attitude towards lockdown. Finally, from the predictive risk model in which $99.9 \%$ of the data fit., the affective factor represents $68 \%$, the cognitive factor $22 \%$, and the behavioral factor $10 \%$ of predictive importance for lockdown attitudes to COVID-19.
\end{abstract}


Keywords: Attitudes, Lockdown, Quarantine, Isolation, COVID-19, Risk, Predictor

\section{Introduction}

There are lessons we can take from history. Several articles have been published documenting the COVID-19 pandemic. Most of them focus on the clinical and epidemiological aspects of the pandemic. Some others address the ravaging effects on the human psyche. The former means that even though science has provided the route to understanding via scientific achievements, the virus, and its symptoms, life remains chaotic for billions from a political, cultural, economic, and psychological perspective.

Thus, social psychology gains relevance to help public understanding of social challenges they face by coexisting with a new, highly contagious virus.

Ajzen and Fishbein (1980) developed a theory of attitudes containing three elements: cognitive, other affective, and behavioral. They stated that behavior is determined by reasoning or knowledge, effectively evaluating a particular situation as positive or negative. The decision is made to act or not, permits predicting behavior (Barón \& Byrne, 2005).

The knowledge that someone believes they are justified as appropriate or sufficient will permit them to opt for or against measures, in this case, quarantine by COVID-19. Their behavior will be guided by such knowledge and evaluation.

Risk factors are those that can generate inappropriate responses in terms of physical, psychological, and social health. The level of risk is determined by the frequency, duration, and intensity of the stimuli (Unda, Uribe, Jurado, García, Tovalín \& Juárez, 2016).

In the case of COVID-19 lockdown, it is enough to review Zimbardo's 1971 Stanford prison experiment (Zimbardo, 1982), to understand the profound implication of risk in which millions of people live in the world that could cause aggression, addictions, and depression among others.

Another essential risk is that of living space. Calhoun's et al. (Myers, 2009) visualized social pathology caused by population density. Calhoun's rodent habitat experiment showed the extent of lockdown required to make the experimental subjects' behavior aberrant. The study provided an understanding of the problems caused by lockdown in social relationships and how it impacts those who react by resisting, enduring, coping, or tolerating an extended period of close physical proximity to others.

His work also allowed Hall et al. (Barón \& Byrne, 2005) to lay the foundations of proxemics with its spatiotemporal dimensions that influence, among other aspects, social restrictions, territoriality, and above all, the 
physical space necessary for a person to feel comfortable when relating to others.

From January to June 2020, there are 8416 documents related to COVID-19 indexed in Scopus and around 70000 in Google Scholar. From those, only 216 (Scopus ${ }^{\circledR}$ ) and 2060 (Google Scholar ${ }^{\circledR}$ ) correspond to the field of social psychology. Therefore, the scientific literature in this discipline is exceptionally scarce.

Furthermore, the fear of the unknown caused by COVID-19 has generated stigma and discriminatory behaviors towards those affected. This further contributes to a situation that already undermines social cohesion in such a way that some people might prefer to hide their illness or delay seeking medical care (Shreyaswi \& Shashwath, 2020). For instance, in India, stigma is prevalent against people who have contracted the virus, healthcare professionals, and, in general, front-line workers (Chatterjee, Bhattacharyya, Bhattacharyya, Gupta, Das, \& Banerjee, 2020). The pandemic has also exacerbated psychological disorders such as anxiety, anguish, and fear in the population, further generating maladaptive responses such as stigma violence. (Matus \& cols., 2020).

According to Shreyaswi and Shashwath (2020), the longer the lockdown, the worse the mental health reported. Specifically, symptoms such as post-traumatic stress, avoidance behaviors, and anger have been recorded. The authors mention that variables generating anxiety include boredom, frustration, financial insecurity, and the feeling of isolation. The media further exacerbate anxiety through sensational headlines and a feeling of bombardment. Shreyaswi and Shashwath (2020) propose establishing a defined strategy to integrate mental health services into the public health response to COVID-19 to mitigate the long-term effects.

Kundapur, Rashmi, Sachin, Falia, Remiza \& Bharadwaj (2020) analyzed disease trends based on available data from various sources, including the WHO, international organizations', governments, and websites. For instance, in India, data was taken from the Ministry of Health, Family, and Welfare websites of individual states since January 2020. The authors propose reconsidering strategies to contain the disease's spread since it is not yet fully understood. Furthermore, they note it is perplexing that there are no differences in approach by demographics. They concluded that it is crucial to have a centralized system collecting information in a standardized way.

Liotta, Marazzi, Orlando \& Palombi (2020) published a study on social connection as a risk factor for the spread of COVID-19 among older adults in Italy. They report that $33 \%$ of the total Italian population lives alone, and $53.1 \%$ cohabit with two people per household. The remaining population averages between 3 and 5 people per household. According to Liotta et al. (2020), more than $50 \%$ of the population aged $85+$ live alone, and in some 
regions of northern Italy, the percentage reaches $75 \%$. This scenario has reduced the risk of virus spread. The results reveal no relationship between social connection and the spread of the virus in older adults.

Meanwhile, in the United States of America, McFadden, Malik, Aguolu, Willebrand, and Omer (2020) reported a study to understand risk perceptions about the COVID-19 outbreak in the adult population. Of 718 participants, $69 \%$ trusted information from scientists. However, the perception of risk was low (5 out of 10$)$.

In Brazil, to profile the population through the expanded model of health beliefs, Fernandes (2020) applied an instrument with 24 items on the perception of risk by COVID-19. The questionnaire included a section related to behaviors and attitudes regarding the motivation to improve health. The sample size was 277 adults.

Fernandes (2020) incorporates psychometric values that prove reliability and validity. The results indicate significant differences in perceived susceptibility and severity dimensions. This approach allows to identify individual beliefs' profiles quickly, directly, and quantitatively for each dimension, enabling effective communication processes and public health education (Fernandes, 2020).

In Paraguay, Rios-González (2020) reported on a cross-sectional study conducted through an online survey on adults, including some university students. The sample was made up of 3,141 people from the country's provinces, including Asunción and its metropolitan area. The results show that 88.35\% have not visited any crowded places. $74.31 \%$ reported having worn a mask when they needed to go out. The global knowledge of essential aspects related to COVID-19 and protection measures was $62 \%$, which is considered low. The result is striking since most of them are university students expected to have greater intelligence and general knowledge. Finally, Rios-González recognizes the necessity of implementing mass education campaigns to increase understanding of COVID-19.

In Mexico, Contreras-Ibáñez (2020) reports high-stress levels among the population, according to the COVIDiStress Global Survey's global parameters. Contreras-Ibáñez (2020) coordinated the application with a sample of 6,424 cases. Among the main results, it stands out that women experience more physical or emotional tension than men. Simultaneously, they face a double journey, and the pressure they feel when trying to carry them out in pandemic conditions leads to additional difficulty. At the same time, it was observed that they face additional responsibilities due to the pandemic.

As of May 30, 2020, in Panama, the number of infected males far exceeds females (7,668 men, representing $59 \%$ of the infected population). The total number of positive cases registered in the country to date is 13,018 
and 330 deaths (2.53\%), according to data provided by the Ministry of Health and the Gorgas Institute (MINSA-GORGAS, 2020).

The most affected group are males between 18 to 30 years old (2,292 cases of infection who represent $18.69 \%$ of the overall infections). This is also the group with the highest risk as it will be discussed later. Next in order of most to least affected are: 31 to 40 years old, or 1,700 (13.86\%) cases, from 41 to 50 years representing 1500 (12.23\%) cases, those from 51 to 60 years 1,000 cases (8.16\%) and individuals from 61 to 80 years 820 (6.69\%) cases. Panama's projected population breakdown as of July 2020 can be seen in graph 1 (INEC, 2019).

Graph No.1. Comparison of the projection of the population pyramid and positive cases for Covid-19 in Panama

Projection of the population pyramid of the Republic of Panama as of July $1,2020$.

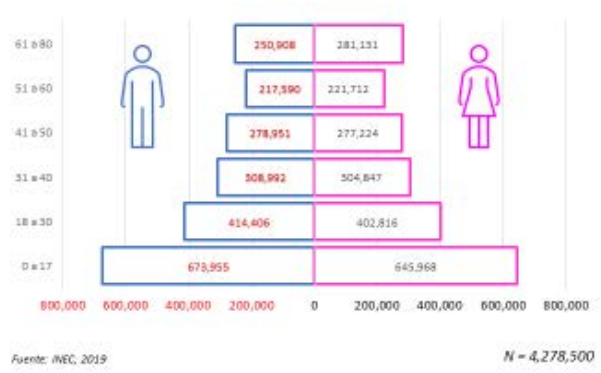

Covid-19 positive cases in Panama as of May 30, 2020

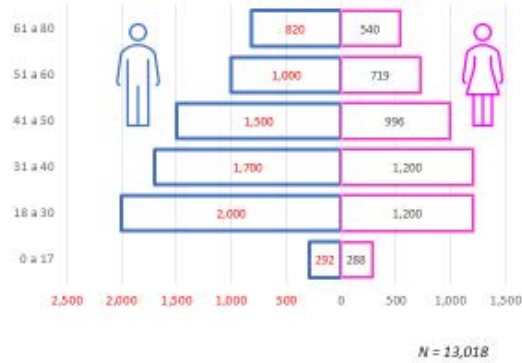

Likewise, women's cases were given the same risk assessment as a function of age. The age group of 18 to 30 leads the list with 1,488 (12.14\%) positive cases. The age group of 31 to 40 years has 1,200 (9.79\%), from 41 to 50 years, 966 (8.12\%); from 51 to 60 years 719 (5.86\%); and 61 to 80 with 547 (4.46\%) cases.

\section{Method}

A cross-sectional, correlational, and predictive study was carried out in Panama to evaluate the attitudes to predict the risk variables before lockdown by COVID-19.

The instrument had two sections. The first section evaluated sociodemographic data; the other, with 36 items on the Likert type scale, measured lockdown attitudes.

The psychometric characteristics had a Cronbach's alpha reliability $\alpha$ $=.921$ and average variance of 53.85\% for three factors (cognitive, affective, and behavioral). The total participants were 233 Panamanian adults of both sexes. The measurements were made between April 17 and April 30, 2020 (Matus \& Matus, 2020). 
The Likert-type scale's 36 items were grouped into three factors (cognitive, affective, and behavioral). Likewise, the full scale was arranged to know the participants' average Attitude, where one is "strongly disagree," and five represents "strongly agree."

The scale has 36 items grouped into three factors: cognitive, affective, and behavioral. Each item can have values from 1 to 5 that correspond to the Likert "type" scale. There may be cases where one or more questions are not answered. To interpret the results, the scores were added and the risk index located

The 12 items that make up the cognitive factor are number $1,2,3,5$, $6,7,16,17,18,19,20,54$. As for a scale, low scores range from 0 - 20 (RISK), average scores range from 21 - 40 (NORMAL), and the high scores range from $41-60$ (HEALTHY).

In the case of the affective factor, the items are: 22, 25, 26, 29, 30, 31, 32, 35, $36,37,39,40,41,42,43$. The low scores range from $0-25$ and are regarded as HEALTHY. Average scores are from 36 - 50 (NORMAL), and high scores range from 51 - 75 (RISK).

The nine questions that make up the behavioral factor are 4, 9, 13, 45, 46, 48, 49, 50, 51 with low scores ranging from 0 - 15 and regarded as RISK; average scores range from 16 - 30 (NORMAL), and the high scores range between 31 - 45 which is considered to be HEALTHY

The instrument recorded sex, age, schooling, occupation, employment status, number of inhabitants in the home (including the person who answered the instrument), number of rooms (considering that 1 living room, 1 dining room, 1 kitchen, 1 bathroom, and 2 bedrooms) and the attitude towards lockdown (variables for risk) from every participant.

The average age of the 78 men was 39 years and 38 in the 155 female participants. The sample consisted of 78 (33.5\%) men and 155 (66.5\%) women. $35 \%$ of the participants reported postgraduate education, $54 \%$ the university level, $8 \%$ have technical studies, and 3\% with high school education (Matus \& Matus, 2020).

Snowball sampling was employed (e.g., emails, WhatsApp, social networks), spreading the instrument by email and WhatsApp.

An ex post facto, cross-sectional, causal correlational non-experimental design with a regression hypothesis $(y=m \cdot x+b)$ was used to predict risk variables for COVID-19. The Appendix of this document presents some statistical analysis of the attitude as a function of different factors.

Finally, it is worth mentioning that the study's limitations are the social desirability bias of the participants and difficulties in accessing the internet. Furthermore, the present study cannot be replicated due to the specific conditions in which the data was collected-everything was measured during 
COVID-19 lockdown. The lockdown measures are now more flexible, and there is knowledge a priori that prevents us from repeating the study.

\section{Results}

In 16 of the 35 items, the Student's T-test revealed significant differences for independent samples. Table 1 shows the results.

Table 1. Differences based on sex

\begin{tabular}{|c|c|c|c|c|c|c|c|}
\hline & \multicolumn{4}{|l|}{ Sex } & \multirow[b]{3}{*}{$\mathrm{t}$} & \multirow[b]{3}{*}{ gl } & \multirow[b]{3}{*}{$\mathrm{P}$} \\
\hline & \multicolumn{2}{|c|}{ Male $n=78$} & \multicolumn{2}{|c|}{ Female $n=155$} & & & \\
\hline & $\overline{\mathrm{x}}$ & $\sigma$ & $\overline{\mathrm{x}}$ & $\sigma$ & & & \\
\hline 11. Work from home & 3.78 & 1.43 & 3.37 & 1.45 & 2.04 & 231.00 & $.04 *$ \\
\hline 36. I study what I like & 3.94 & 1.7 & 3.47 & 1.25 & 2.95 & 176.82 & $.00^{* *}$ \\
\hline 33. I exercise & 3.33 & 1.33 & 2.96 & 1.34 & 2.01 & 231.00 & $.05 *$ \\
\hline 25. I feel like a prisoner & 1.90 & 1.11 & 2.38 & 1.26 & -2.99 & 172.66 & $.00^{* *}$ \\
\hline 20. I feel isolated & 2.05 & 1.17 & 2.58 & 1.38 & -3.06 & 178.59 & $.00 * *$ \\
\hline 24. I feel worried & 2.72 & 1.23 & 3.09 & 1.35 & -2.05 & 231.00 & $.04 *$ \\
\hline 15. I feel helpless & 1.86 & 1.08 & 2.44 & 1.31 & -3.60 & 183.34 & $.00 * *$ \\
\hline 14. I feel vulnerable & 2.08 & 1.15 & 2.74 & 1.35 & -3.92 & 178.52 & $.00 * *$ \\
\hline 18. I feel scared & 2.24 & 1.19 & 2.70 & 1.28 & -2.62 & 231.00 & $.01^{* *}$ \\
\hline 21. I feel angry & 1.83 & 1.04 & 2.25 & 1.20 & -2.58 & 231.00 & $.01^{* *}$ \\
\hline 19. I feel annoyed & 1.78 & 1.04 & 2.34 & 1.34 & -3.47 & 191.74 & $.00 * *$ \\
\hline 17. I feel in danger & 2.15 & 1.22 & 2.63 & 1.32 & -2.64 & 231.00 & $.01^{* *}$ \\
\hline 13. I feel confused & 1.91 & 1.10 & 2.54 & 1.35 & -3.79 & 186.04 & $.00 * *$ \\
\hline 22. I feel uncertain & 2.50 & 1.33 & 3.01 & 1.31 & -2.80 & 231.00 & $.01^{* *}$ \\
\hline 34. I talk with my friends. & 3.86 & 1.09 & 3.51 & 1.17 & 2.20 & 231.00 & $.03 *$ \\
\hline 29. I dance & 2.47 & 1.48 & 2.92 & 1.38 & -2.28 & 231.00 & $.02 *$ \\
\hline
\end{tabular}

The results indicate that women are at risk psychosocial, considering that the averages obtained are significantly lower than men in questions 11 , 36,33 , and 34 . The situation is more delicate for males than females since they have low scores on items 13, 14, 15, 17, 18, 19, 20, 21, 22, 24, 25, and 29. Table 2 shows the differences by age group. The grouping criterion is related to the information on the highest epidemiological incidence of Covid-19 infection in Panama. The items that do not appear, such as 13 and 18, are due to no statistically significant differences.

Table 2. Differences by age group

\begin{tabular}{|l|l|l|l|l|l|l|l|}
\hline & \multicolumn{2}{l|}{ Age group } & & & \\
\hline & \multicolumn{1}{l}{$\begin{array}{l}18-50 \\
\mathrm{n}=186\end{array}$} & \multicolumn{2}{l|}{$\begin{array}{l}\mathrm{n}-80 \\
\mathrm{n}=46\end{array}$} & & & \\
\hline & $\overline{\mathrm{x}}$ & $\sigma$ & $\overline{\mathrm{x}}$ & $\sigma$ & $\mathrm{t}$ & $\mathrm{gl}$ & $\mathrm{p}$ \\
\hline 10. I eat the necessary & 3.78 & 1.13 & 4.15 & 1.01 & -2.01 & 230.00 & $.05^{*}$ \\
\hline 08. I watch tv news & 3.21 & 1.25 & 3.93 & 1.00 & -4.18 & 83.61 & $.00^{* *}$ \\
\hline 11. I work from home & 3.38 & 1.48 & 4.04 & 1.21 & -3.17 & 81.79 & $.00^{* *}$ \\
\hline
\end{tabular}




\begin{tabular}{|l|l|l|l|l|l|l|l|}
\hline 36. I study what I like & 3.53 & 1.22 & 3.98 & 1.11 & -2.26 & 230.00 & $.02^{*}$ \\
\hline 02. I wash my hands & 4.23 & 1.00 & 4.63 & 0.68 & -3.26 & 99.21 & $.00^{* *}$ \\
\hline $\begin{array}{l}\text { 01. I inform myself about } \\
\text { COVID-19 }\end{array}$ & 3.88 & 1.05 & 4.37 & 0.80 & -2.95 & 230.00 & $.00^{* *}$ \\
\hline $\begin{array}{l}\text { 05. I talk with my family } \\
\text { about COVID-19 }\end{array}$ & 3.72 & 1.14 & 4.17 & 1.16 & -2.40 & 230.00 & $.02^{*}$ \\
\hline 33. I exercise & 2.97 & 1.33 & 3.52 & 1.33 & -2.51 & 230.00 & $.01^{* *}$ \\
\hline $\begin{array}{l}\text { 03. I know how COVID-19 } \\
\text { transmits. }\end{array}$ & 4.14 & 0.94 & 4.48 & 0.75 & -2.26 & 230.00 & $.02^{*}$ \\
\hline $\begin{array}{l}\text { 04. I know what to do in } \\
\text { case that I am a COVID-19 } \\
\text { patient. }\end{array}$ & 3.99 & 1.02 & 4.35 & 0.79 & -2.19 & 230.00 & $.03^{*}$ \\
\hline $\begin{array}{l}\text { 12. I forward truthful } \\
\text { information }\end{array}$ & 3.63 & 1.24 & 4.24 & 0.87 & -3.87 & 95.03 & $.00^{* *}$ \\
\hline $\begin{array}{l}\text { 06. I can identify COVID } \\
\text { Identify the symptoms de } \\
\text { Covid-19 }\end{array}$ & 3.82 & 1.09 & 4.28 & 0.91 & -2.64 & 230.00 & $.01^{* *}$ \\
\hline $\begin{array}{l}\text { 09. I know the Ministry of } \\
\text { Health Decrees }\end{array}$ & 3.68 & 1.12 & 4.15 & 0.97 & -2.89 & 77.64 & $.00^{* *}$ \\
\hline 17. I feel in danger & 2.39 & 1.27 & 2.83 & 1.42 & -2.06 & 230.00 & $.04^{*}$ \\
\hline 31. I do manual activities & 2.67 & 1.44 & 3.26 & 1.32 & -2.54 & 230.00 & $.01^{* *}$ \\
\hline 32. I read & 3.32 & 1.38 & 3.96 & 1.17 & -3.19 & 78.63 & $.00^{* *}$ \\
\hline 30. I write & 2.73 & 1.48 & 3.37 & 1.39 & -2.76 & 72.42 & $.01^{* *}$ \\
\hline 35. I watch TV & 3.03 & 1.37 & 3.80 & 0.96 & -4.46 & 97.85 & $.00^{* *}$ \\
\hline
\end{tabular}

Those over 50 years of age obtained higher averages in the 18 questions that had statistically significant differences. Tables 3 and 4 show the statistically significant differences by sex, age group, and factors.

Table 3. Differences by sex and factor

\begin{tabular}{|c|c|c|c|c|c|c|c|}
\hline & \multicolumn{4}{|c|}{ Sex } & & & \\
\hline & \multicolumn{2}{|c|}{ Male $\mathrm{n}=78$} & \multicolumn{2}{|c|}{ Female $\mathrm{n}=155$} & & & \\
\hline & $\overline{\mathrm{x}}$ & $\sigma$ & $\overline{\mathrm{x}}$ & $\sigma$ & $\mathrm{t}$ & gl & $\mathrm{p}$ \\
\hline Affective Factor & 2.18 & 0.86 & 2.64 & 0.90 & -3.76 & 160.23 & $.00 * *$ \\
\hline
\end{tabular}

Although the averages for both sexes are low, men are more emotionally vulnerable than women.

Table 4. Differences by age group and factor

\begin{tabular}{|c|c|c|c|c|c|c|c|}
\hline & \multicolumn{4}{|c|}{ Age } & & & \\
\hline & \multicolumn{2}{|c|}{$\begin{array}{l}18-50 \\
n=186\end{array}$} & \multicolumn{2}{|c|}{$\begin{array}{l}51-80 \\
n=46\end{array}$} & & & \\
\hline & $\overline{\mathrm{x}}$ & $\sigma$ & $\overline{\mathrm{x}}$ & $\sigma$ & $\mathrm{t}$ & gl & $\mathrm{p}$ \\
\hline Cognitive factor & 3.80 & 0.85 & 4.27 & 0.61 & -4.27 & 92.03 & $.00 * *$ \\
\hline Behavioral factor & 2.72 & 0.85 & 3.07 & 0.78 & -2.49 & 230.00 & $.01 * *$ \\
\hline
\end{tabular}


Participants in the age group between 51 and 80 show higher cognitive and behavioral values. The following table shows the scores of general attitudes concerning age groups. Table 6 indicates the values of the correlation analysis.

Table 5. Attitudes and differences by age group

\begin{tabular}{|c|c|c|c|c|c|c|c|}
\hline & \multicolumn{4}{|c|}{ Age group } & & & \\
\hline & \multicolumn{2}{|c|}{$\begin{array}{l}18-50 \\
n=186\end{array}$} & \multicolumn{2}{|c|}{$\begin{array}{l}51-80 \\
\mathrm{n}=46\end{array}$} & & & \\
\hline & $\overline{\mathrm{x}}$ & $\sigma$ & $\overline{\mathrm{x}}$ & $\sigma$ & $\mathrm{t}$ & gl & $\mathrm{p}$ \\
\hline Attitudes & 2.90 & 0.61 & 3.16 & 0.55 & -2.59 & 230.00 & $.01^{* *}$ \\
\hline
\end{tabular}

Table 6. Pearson's $r$ correlation

\begin{tabular}{|c|c|c|c|c|c|}
\hline & & $\begin{array}{l}\text { Cognitive } \\
\text { Factor }\end{array}$ & $\begin{array}{l}\text { Affective } \\
\text { Factor }\end{array}$ & $\begin{array}{l}\text { Behavioral } \\
\text { Factor }\end{array}$ & Attitude \\
\hline \multirow[t]{3}{*}{$\begin{array}{l}\text { Cognitive } \\
\text { Factor }\end{array}$} & $\begin{array}{l}\text { Pearson } \\
\text { Correlation. }\end{array}$ & 1 & $.225^{* *}$ & $.634^{* *}$ & $.789^{* *}$ \\
\hline & Sig. (bilateral) & & 0.001 & 0.000 & 0.000 \\
\hline & $\mathrm{N}$ & & 233 & 233 & 233 \\
\hline \multirow[t]{3}{*}{$\begin{array}{l}\text { Affective } \\
\text { Factor }\end{array}$} & $\begin{array}{l}\text { Pearson } \\
\text { Correlation. }\end{array}$ & & 1 & 0.040 & $.731^{* *}$ \\
\hline & Sig. (bilateral) & & & 0.547 & 0.000 \\
\hline & $\mathrm{N}$ & & & 233 & 233 \\
\hline \multirow[t]{3}{*}{$\begin{array}{l}\text { Behavioral } \\
\text { Factor }\end{array}$} & $\begin{array}{l}\text { Pearson } \\
\text { Correlation. } \\
\end{array}$ & & & 1 & $.615^{* *}$ \\
\hline & Sig. (bilateral) & & & & 0.000 \\
\hline & $\mathrm{N}$ & & & & 233 \\
\hline \multirow[t]{3}{*}{ Attitude } & $\begin{array}{l}\text { Pearson } \\
\text { Correlation. } \\
\end{array}$ & & & & 1 \\
\hline & Sig. (bilateral) & & & & \\
\hline & $\mathrm{N}$ & & & & \\
\hline
\end{tabular}

There is a strong and direct statistically significant relationship between the three factors and attitudes. The result is summarized in tables 7 and 8.

For the predictive model, the data was subjected to linear regression analysis. The predictive risk model has a $99.9 \%$ data fit with a significance of 0.001, as shown in Graph No.2. The correlation for the other factors and attitudes is presented in the Appendix.

Table 7. Linear regression analysis

\begin{tabular}{|l|l|l|l|l|l|l|}
\hline Effect & $\begin{array}{l}\text { Sum } \\
\text { of } \\
\text { square } \\
\text { s }\end{array}$ & gl & $\begin{array}{l}\text { Quadrati } \\
\text { c } \\
\text { Average }\end{array}$ & $F$ & p & $\begin{array}{l}\text { Relevanc } \\
\text { e }\end{array}$ \\
\hline Corrected Attitude model & 85.14 & 4 & 14.19 & $\begin{array}{l}10,852.3 \\
8\end{array}$ & $\begin{array}{l}0.00 \\
0\end{array}$ & \\
\hline
\end{tabular}




\begin{tabular}{|lr|l|l|l|l|l|l|}
\hline $\begin{array}{l}\text { Transformed } \\
\text { factor. }\end{array}$ & Affective & 29.56 & 1 & 29.56 & $\begin{array}{l}22,603.6 \\
2\end{array}$ & $\begin{array}{l}0.00 \\
0\end{array}$ & 0.68 \\
\hline $\begin{array}{l}\text { Cognitive } \\
\text { transformed. }\end{array}$ & factor & 9.43 & 1 & 9.43 & $7,213.43$ & $\begin{array}{l}0.00 \\
0\end{array}$ & 0.22 \\
\hline $\begin{array}{l}\text { Behavioral } \\
\text { transformed. }\end{array}$ & factor & 4.44 & 1 & 4.44 & $3,394.79$ & $\begin{array}{l}0.00 \\
0\end{array}$ & 0.10 \\
\hline Remainder & & 0.30 & $\begin{array}{l}22 \\
8\end{array}$ & 0.00 & & & \\
\hline Corrected total & & 85.44 & 23 & & & & \\
\hline
\end{tabular}

Table 8. Risk prediction model

\begin{tabular}{|l|l|l|l|l|l|l|l|}
\hline Model & $\mathrm{F}$ & $\mathrm{R} 2$ & $\wedge \mathrm{R} 2$ & $\mathrm{~B}$ & $\begin{array}{l}\text { Standard } \\
\text { Error }\end{array}$ & $\beta$ & $\mathrm{p}$ \\
\hline $\begin{array}{l}\text { Model 1 } \\
\text { Affective }\end{array}$ & $\begin{array}{l}34560.006 \\
(3-229)\end{array}$ & 0.998 & 0.998 & 0.411 & 0.002 & 0.615 & .001 \\
\hline
\end{tabular}

Graph No.2. The observed prognosis for Attitude corresponding to the linear risk model

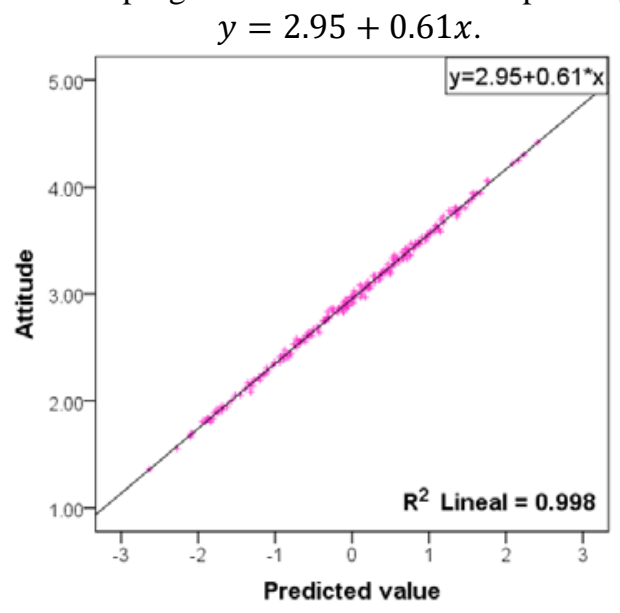

\section{Discussion}

Businessman ranging 18 and 30 years old, have considerable psychosocial risk factors due to lockdown. These findings agree with those reported by Kundapur et al. (2020) regarding young people belonging to the most vulnerable group in many countries. This discovery is particularly worrying since not only is the rate of transmission and death from the virus higher in men, but they are also more exposed to psychosocial risk factors. In other words, it implies that susceptibility appears both in the biological, as well as the psychological and social spheres.

Females showed a better result in the affective factor, which contrasts with the results reported by Contreras-Ibáñez (2020), who points out that women experience more emotional tension and feel additional pressure when 
trying to face their double burden in a pandemic situation. Thus, affective management differs among the female population depending on the geographic region.

The differences between men and women coincide with those reported by Bischof, Oertelt-Prigione, Morgan, and Klein (2020). These authors mention that it is essential to differentiate between women and men due to their vulnerability, especially men, who are exposed due to their behavior. Social norms and other socially relevant variables change with culture. Likewise, Buzzi, Tucci, Ciprandi, Brambilla, Caimmi, Ciprandi, and Marseglia (2020) found that male adolescents have a worse attitude towards lockdown than women. The authors justify this situation because men are socially related outdoors, unlike women.

Regarding the differences by age, this study partially coincides with that reported by Liotta, Marazzi, Orlando, and Palombi (2020), regarding the spread of the virus among older adults in Italy, by household size and population structure. The age group under 51 years of age has a higher risk of contagion. This result coincides with those reported by Joo and Kang (2020), who mention that young generations have the highest percentage of confirmed cases.

Czeisler et al. (2020) state a significant association between the feeling of security against COVID-19 and the age of young adults, implying they do not perceive a risk of infection or severe disease compared to those over 65 years old. It is also worrisome that, if coexistence is carried out in violation of the inhabitants' living space, it becomes counterproductive, potentially triggering erratic and violent behavior, as demonstrated by Calhoun (1962) and Hall (1966).

Finally, the lack of knowledge about COVID-19 that was evidenced by the sample of business people is striking, since they urge or pressure the national authorities to suspend lockdown for the economy's reactivation, even against the preventive measures that the Ministry of Health has given daily.

\section{Conclusions}

Regardless of the COVID- 19's well-known lethality, those individuals sampled neglect social distancing, and stay-at-home measures. This situation is causing a geometric progression of positive cases.

People are facing a series of unprecedented changes. Until recently, it had been possible to contain viruses in some regions of the world. However, the population cannot comply with the recommendations from the epidemiologists, which requires further investigation. Professionals in social psychology have assumed the responsibility of identifying risk by measuring attitudes from the theory of Fishbein and Ajzen to predict behavior. 
Women have a better attitude towards lockdown, which represents a protection factor. As for age, there is a stark contrast between those over 51 years old compared to young adults (18 to 50 years old). The latter being those who are at risk and, according to national data, it is also the population containing more positive cases of COVID-19.

In terms of the number of rooms, the average is 7 . Thus, the average house has at least one living room, one dining room, one kitchen, one bathroom, and three bedrooms, which, related to the average number of people (up to six) that coexist, seems to be limit for a healthy coexistence. Those at most psychosocial risk of not knowing what to do during the quarantine are young people between 18 and 30 who have elementary education. Regarding the affective factor, men between 18 and 30 years old are the most exposed. We also conclude that despite the remaining sample being at lower risk, overall, the emotional impact is overwhelming. Finally, the risk due to unfavorable attitudes towards lockdown by Covid-19 are again men from 18 to 30 years old and, in general, entrepreneurs.

Within the inferential results, observed perceived significant differences in the vulnerability of men concerning women. The same goes for people younger than 50 years old, which reveals a possible risk profile.

We also verified a strong and direct correlation between attitudes' affective, cognitive, and behavioral factors.

We found that the data fit a linear correlation that allowed us to conclude that the contagion risk among Panamanians is mainly due to the affective factor. People are incapable of managing their emotions.

Finally, we highlight the low number of studies in Panama related to psychosocial risk and studies associated with the pandemic.

\section{Conflict of interest}

The authors declare that they do not have a competing interest in conducting and reporting this study. This research has been shown following the American Psychology Association Code of Conduct and the authors' national ethics guidelines. Participation was voluntary, and anonymity has been guaranteed. The submitted work is an original manuscript and has not been published entirely nor in part in other journals or media outlets.

\section{Funding}

This study was supported by SENACYT, Panamá: Grant APY19-009, and the Grant MINBUZA-2020.926889 from the Department of European Integration, Netherlands. 


\section{References:}

1. Ajzen, I. (1987). Attitudes, traits, and actions: Dispositional prediction of behavior in personality and social psychology. In L. Berkowitz (Ed.), Advances in experimental social psychology, 20. San Diego, CA: Academic Press.

2. Ajzen, I. (1991). The theory of planned behavior. Organizational Behavior and Human Decision Processes, 50(2), 179-211.

3. Ajzen, I., \& Fishbein, M. (1980). Understanding attitudes and predicting social behavior. Englewood Cliffs, NJ: Prentice-Hall.

4. Barón, R. A \& Byrne, D. (2005). Psicología Social. Madrid: Pearson / Prentice Hall

5. Bischof, E., Oertelt-Prigione, S., Morgan, R., Klein, S. L., (2020). Towards Precision Medicine: Inclusion of Sex and Gender Aspects in COVID-19 Clinical Studies-Acting Now before It Is Too Late-A Joint Call for Action. International Journal of Environmental Research and Public Health, 17(10). https://doi.org/10.3390/ijerph17103715

6. Buzzi, C., Tucci, M., Ciprandi, R., Brambilla, I., Caimmi, S., Ciprandi, G., \& Marseglia, G. L. (2020). The psychosocial effects of COVID-19 on Italian adolescents' attitudes and behaviors. Italian Journal of Pediatrics, 46(1), 1-7. https://doi.org/10.1186/s13052-020-00833-4

7. Calhoun J. B. (1962). Population density and social pathology. Scientific American, 306: 139-48.

8. Calhoun J. B. (January 1973). Death squared: The explosive growth and demise of a mouse population. Proceedings of the Royal Society of Medicine, 66 (1 Pt 2) 80-88.

9. Chatterjee, S., Bhattacharyya, R., Bhattacharyya, S., Gupta, S., Das, S., \& Banerjee, B. (2020). Attitude, practice, behavior, and mental health impact of COVID-19 on doctors. Indian Journal of Psychiatry, 62(3),

257-265.

https://doi.org/10.4103/psychiatry.IndianJPsychiatry_333_20

10. Contreras-Ibáñez, C., Flores, R., Reynoso-Alcántara, V., Pérez-Gay, F., Castro, C., \& Martínez, L. (2/jun/2020). Socioeconomic and situational conditions associated with stress, at the start of the COVID19 pandemic. Entorno UDLAP. Edición especial. https://drive.google.com/file/d/1T9NwVqgd-

Sj3HhFs_PKQ3i34_df7jrQT/view?fbclid=IwAR2s3KTsuhGYByvx8 gBaBlBKI1Q6-v0gM9aTeEzVmTkDslmZcvJiMCqln_U

11. Czeisler, M. É., Tynan, M. A., Howard, M. E., Honeycutt, S., Fulmer, E. B., Kidder, D. P., Robbins, R., Barger, L. K., Facer-Childs, E. R., Baldwin, G., Rajaratnam, S. M. W., \& Czeisler, C. A. (2020). Public Attitudes, Behaviors, and Beliefs Related to COVID-19, Stay-atHome Orders, Nonessential Business Closures, and Public Health 
Guidance - United States, New York City, and Los Angeles, May 512, 2020. MMWR: Morbidity \& Mortality Weekly Report, 69(24), 751-758. https://doi.org/10.15585/mmwr.mm6924e1

12. Fernandes, M. (2020). Health belief model for coronavirus infection risk determinants. RSP. Revista Saúde Pública, 54 (47), 54:47. 1http: //doi.org/10.11606/s1518-8787.2020054002494

13. Hall, E. (2003). La dimensión oculta. México: Siglo XXI.

14. Haney, C., Banks, W. C., \& Zimbardo, P. G. (1973) A study of prisoners and guards in a simulated prison. Naval Research Review, 30, 4-17.

15. INEC (2019) Estimación y proyección de la población de la República de Panamá, según sexo y edad al 1 de julio de 2020. Instituto Nacional de Estadística y Censo. Recuperado de https://www.inec.gob.pa/publicaciones/Default3.aspx?ID_PUBLICA CION=499\&ID_CATEGORIA=3\&ID_SUBCATEGORIA $=10$

16. Joo, H. \& Kang, Y. (2020). COVID-19 Infection in South Korea: Focusing on age distribution of confirmed cases. Journal of Pure \& Applied Microbiology, 14, 721-723. https://doi.org/10.22207/JPAM.14.SPL1.08

17. Kundapur, R., Rashmi, A., Sachin M., Falia, K., Remiza R. A., \& Bharadwaj, S. (2020). COVID-19 - Observations and speculations -A trend analysis. Indian Journal of Community Health, 32(2), 300305.

18. Liotta, G., Marazzi, M. C., Orlando, S., \& Palombi, L. (2020). Is social connectedness a risk factor for the spreading of COVID-19 among older adults? The Italian paradox. PLoS ONE, 1-7. https://doi.org/10.1371/journal.pone.0233329.

19. Matus, E., Matus, L., Florez, A., Stanziola, M., Araguás, N., López, A., \& Guerra, L. (2020). Estrés en Panamá por COVID-19. Revista Cubana de Alternativas en Psicología, 8 (24), 120-135. Recuperado de http://www.alfepsi.org/revista-alternativas-cubanas-en-psicologiavol8-n24/?fbclid=IwAR1-UgseGUSfCBzxdSvV7V0cnZAtNxQP5SiNja2LM7f5oRGX7y$\mathrm{m} 2$ _CCAE

20. Matus, E. \& Matus, L. (2020). Escala de actitudes hacia el confinamiento por COVID-19-19. Propiedades psicométricas. DOI: 10.5281/zenodo.3840712. Repositorio COVID-19-. ZENODO.ORG. https://nam11.safelinks.protection.outlook.com/?url=https\%3A\%2F \%2Fzenodo.org\%2Frecord\%2F3840712\%23.XsiVx2hKjb0\&data $=02$ \%7C01\%7C\%7C8199dc37acf840a78a7b08d7fec834a1\%7C84df9e7f e9f640afb435aaaaaaaaaaaa\%7C1\%7C0\%7C637258008134421474\& 
sdata=BfeWHuhexlCVRvwtrf5KRQpGKxpmsUkRfyi9Gs7TjF0\%3 D\&reserved $=0$

21. Matus, E. (9 de abril de 2020). Distancia social o espacio vital. La Estrella de Panamá. Recuperado de https://www.laestrella.com.pa/nacional/200409/distancia-socialespacio-vital.

22. Matus, G. L. (1993). Manual de Psicología Social. México: Universidad Iberoamericana.

23. McFadden, S. M., Malik, A. A., Aguolu, O. G., Willebrand, K. S., \& Omer, S. B. (2020). Perceptions of the adult US population regarding the novel coronavirus outbreak. PLoS ONE, 15(4), 1-6. https://doi.org/10.1371/journal.pone.0231808

24. MINSA-GORGAS (2020). Ministerio de Salud de la República de Panamá. Recuperado de https://geosocial.maps.arcgis.com/apps/opsdashboard/index.html\#/2c 6e932c690d467b85375af52b614472

25. Myers, D. (2009). Psicología Social. México: McGraw Hill.

26. Rios-González, C. (2020). Knowledge, attitudes, and practices towards COVID-19 in Paraguayans during outbreaks: a quick online survey. Instituto Nacional de Salud. DOI: https://doi.org/10.1590/SciELOPreprints.149

27. Shreyaswi Sathyanath, M., \& Shashwath Sathyanath M. (2020). Stigma reduction and provision of mental health services in the public health response to COVID-19. Indian Journal of Community Health, 32(2), 269-272.

28. Unda, S., Uribe, F., Jurado, S., García, M., Tovalín, H. \& Juárez, A. (2016). Construction of a scale for assessing at work psychosocial risk factors in professors. Journal of Work and Organizational Psychology, 32 (2), 67-74. https://doi.org/10.1016/j.rpto.2016.04.004

29. WHO (2020). Coronavirus disease (COVID-19) pandemic. World Health Organization. https://www.who.int/home

30. Zimbardo, P. (1982). Pathology of Imprisonment, in D. Krebs (ed.), Readings in Social Psychology: Contemporary Perspectives, Second Ed. (Harper \& Row, New York, NY), 249-251.

\section{Appendix 1}

\section{Instruments and correlations.}

A survey was carried out through Google forms (C), between April 17 and 30, 2020. The study had 233 participants (78 male and 155 female). The average age for males was 39 years old, and for females, it was 38 . Descriptive statistics were employed to characterize the sample: $35 \%$ of the participants reported having studied at least a postgraduate degree, 54\% the university 
level, eight percent a technician, and three percent, studied secondary. A Ttest was used to determine statistically significant differences in the Attitude of men and women towards lockdown. 16 of the 36 items resulted in statistically significant differences between men and women. Furthermore, women are at risk considering that the averages obtained are significantly lower than those of men in question 11. I work from home $(\bar{X}=3.37$, d.s. 1.45), 36. I study what I like ( $\bar{X}=3.47$, d.s. 1.25$)$, 33. I exercise $(\bar{X}=2.96$, d.s. 1.34), y 34. I talk with my friends $(\bar{X}=3.51$, d.s. 1.17).

For males, the situation is more delicate since items 13. I feel confused $(\bar{X}=$ 1.91, d.s. 1.10), 14. I feel vulnerable $(\bar{X}=2.08$, d.s. 1.15), 15. I feel helpless $(\bar{X}=1.86$, d.s. 1.08$), 17$. I feel in danger $(\bar{X}=2.15$, d.s. 1.22$)$, 18. I feel scared $(\bar{X}=2.24$, d.s. 1.19), 19. I feel upset $(\bar{X}=1.78$, d.s. 1.04), 20. I feel isolated $(\bar{X}=2.05$, d.s. 1.17), 21. I feel angry $(\bar{X}=1.83$, d.s. 1.04), 22. I feel uncertain $(\bar{X}=2.50$, d.s. 1.33$), 24$. I feel worried $(\bar{X}=2.72$, d.s. 1.23$)$, 25. I feel imprisoned $(\bar{X}=1.90$, d.s. 1.11$)$, 29. I dance $(\bar{X}=2.47$, d.s. 1.48$)$, they are significantly less than in women, in addition to the affective factor $(\bar{X}=2.18$, d.s. 0.86).

\section{Item Response Dimension}

The participants' responses were subjected to an analysis called the reagent discrimination index, which identifies each item's effectiveness. In this case, the high scores were compared with the low ones through the parametric inferential statistics test for the T-Test for independent samples. The items (which are statistically different) are effective. Next, we tested the reliability analysis of the test, which allows verifying the possible generalization of the results to similar populations and their replicability (Dorantes, 2018). For this purpose, we decided to use the inferential statistical analysis called Cronbach's Alpha. The results show that the total scale is reliable because it presents a score $\alpha=0.921$. In this case, it is a question of high external or global reliability. Subsequently, a construct validity analysis was performed through the so-called factor analysis statistic. For factor analysis, the method of principal components normalization Varimax with Kariser was used, and it converged in 5 iterations. The items that make up the factors, the weights of the factor loadings, the corrected total item correlation ( $\mathrm{r}_{\mathrm{it}}$ ), and the factors' reliability are detailed in the following tables.

Table A1. Factorial Structure of Attitudes towards the quarantine by Covid-19

\begin{tabular}{|l|l|l|l|}
\hline \multicolumn{4}{|c|}{ Factor 1. Cognitive (Alpha =0.925) } \\
\hline \multicolumn{3}{|c|}{ Explained Variance = 23.00\% } & Carga \\
\hline No. & Reactivo & $\mathrm{r}_{\mathrm{it}}$ & 0.84 \\
\hline 06 & I inform myself about COVID-19 & 0.81 & 0.83 \\
\hline 05 & I wash my hands & 0.81 & 0.81 \\
\hline 16 & I know how COVID-19 transmits & 0.82 & \\
\hline
\end{tabular}




\begin{tabular}{|l|l|l|l|}
\hline 17 & $\begin{array}{l}\text { I know what to do in case that I am a COVID- } \\
19 \text { patient. }\end{array}$ & 0.76 & 0.76 \\
\hline 07 & I talk with my family about COVID-19 & 0.70 & 0.74 \\
\hline 19 & I can identify COVID symptoms. & 0.76 & 0.74 \\
\hline 54 & I comply with the quarantine & 0.70 & 0.71 \\
\hline 02 & I see the news & 0.63 & 0.68 \\
\hline 20 & 09. I know the Ministry of Health Decrees & 0.69 & 0.68 \\
\hline 01 & I eat the necessary & 0.57 & 0.63 \\
\hline 03 & I work from home & 0.52 & 0.63 \\
\hline 18 & I forward trustworthy information & 0.60 & 0.62 \\
\hline
\end{tabular}

Table A2. Estructura Factorial de Actitudes ante la cuarentena por Covid-19

\begin{tabular}{|c|c|c|c|}
\hline \multicolumn{4}{|c|}{ Factor 2. Cognitive $($ Alfa $=0.927)$} \\
\hline \multicolumn{4}{|c|}{ Explained Variance $=21.34 \%$} \\
\hline No. & Reactivo & $\mathrm{r}_{\mathrm{it}}$ & Carga \\
\hline 42 & I feel confused & 0.76 & 0.81 \\
\hline 31 & I feel vulnerable & 0.76 & 0.81 \\
\hline 30 & I feel defenseless & 0.75 & 0.80 \\
\hline 32 & I feel overwhelm & 0.68 & 0.74 \\
\hline 40 & I feel in danger & 0.72 & 0.73 \\
\hline 35 & I feel scared & 0.70 & 0.73 \\
\hline 39 & I feel annoyed & 0.63 & 0.71 \\
\hline 26 & I feel isolated & 0.64 & 0.69 \\
\hline 36 & I feel angry & 0.61 & 0.69 \\
\hline 43 & I feel uncertain & 0.65 & 0.69 \\
\hline 41 & I feel tired & 0.63 & 0.68 \\
\hline 29 & I feel worried & 0.65 & 0.67 \\
\hline 25 & I feel like a prisioner & 0.56 & 0.62 \\
\hline 37 & I feel at risk & 0.57 & 0.60 \\
\hline 22 & I Font trust the authorities & 0.44 & 0.48 \\
\hline
\end{tabular}

Table A3. Factorial Structure of Attitudes towards the quarantine by Covid-19

\begin{tabular}{|c|c|c|c|}
\hline \multicolumn{3}{|c|}{ Factor 3. Behavioral (Alfa $=0.849)$} \\
\hline \multicolumn{3}{|c|}{ Explained Variance $=5.51 \%$} \\
\hline No. & Reactivo & $\mathrm{r}_{\text {it }}$ & Carga \\
\hline 50 & I sing & 0.61 & 0.78 \\
\hline 51 & I dance & 0.56 & 0.72 \\
\hline 49 & Escribo & 0.66 & 0.70 \\
\hline 45 & I do manual activities & 0.57 & 0.63 \\
\hline 48 & I read & 0.66 & 0.59 \\
\hline 09 & I do excersise & 0.53 & 0.56 \\
\hline 46 & I chat with my friends & 0.59 & 0.40 \\
\hline 13 & I watch Television & 0.41 & 0.16 \\
\hline 04 & I study what I want & 0.52 & 0.30 \\
\hline
\end{tabular}

The instrument had external and internal reliability and content and construct validity, as shown in the previous tables. 


\section{Linear model}

Linear regression was calculated from the factors to know the effect that each of them has on attitudes towards lockdown, finding a model $y=$ $2.95+0.61 x$, with a linear $\mathrm{R}^{2}=0.998$. This is shown in Graph A1. The relationship between attitude and affective, cognitive, and behavioral factors is established in Graph A2.

Graphs A2, A3, and A4 show the positive relationship that exists between attitudes and each one of the factors. The relationship between the cognitive factor and the Attitude is direct, positive, and strong, which is evidenced by the value of the linear R2 $=0.623$ (Graph A2).

The three factors that make up the attitudes allow us to visualize the dispersion in each of them. The lowest values in the distribution belong to the cognitive factor since the participants knew about the virus. Thus, they were aware of the prevention protocol.

The relationship between the affective factor and the Attitude is direct, positive, and moderate, which is evident in the value of the linear R2 $=0.534$. For the affective factor, there is greater dispersion in the responses, possibly due to changes in the way they managed their emotions. This is sumarized in Graph A3.

The relationship between the behavioral factor and Attitude is direct, positive, and weak, evidenced by the value of linear $\mathrm{R}^{2}=0.379$. The largest dispersion is perceived in the behavioral factor; these values could be related to the population's autonomy even when the Health Authorities instituted curfews and a full quarantine. The relationship is shown in Graph A4.

Graph A1. Linear correlation for the predictive model.

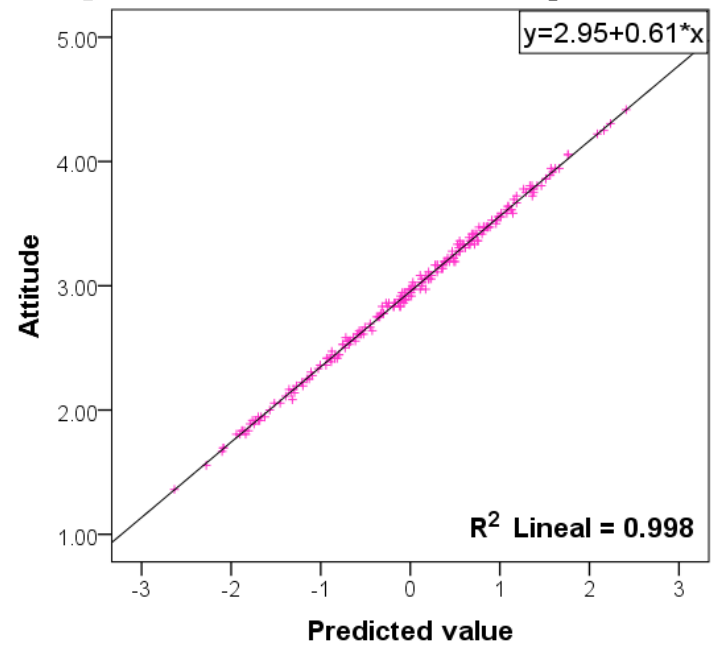


Graph A2. Linear correlation for the affective factor v. Attitude

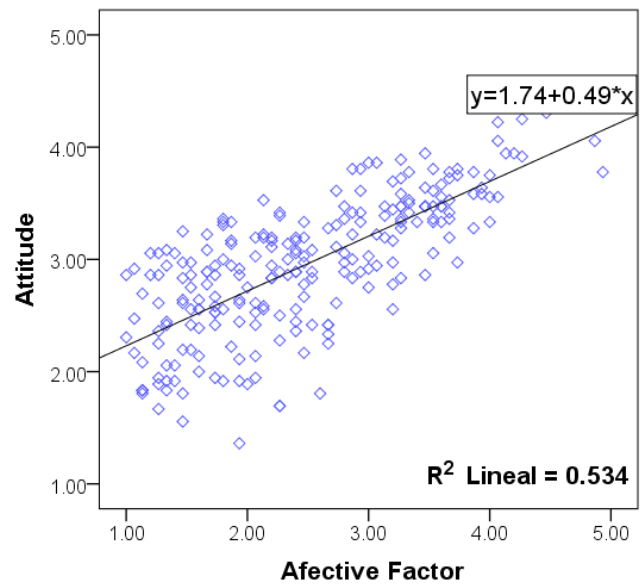

Graph A3. Linear correlation for the cognitive factor v. Attitude. The highest dispersion is observed in this factor

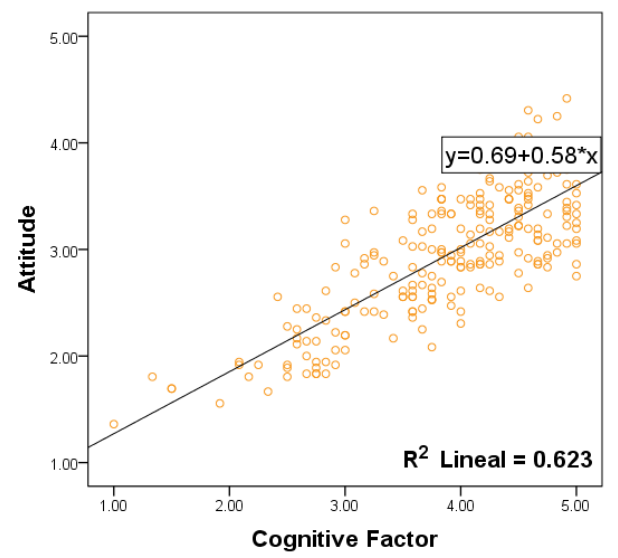

Graph A4. Linear correlation for the behavior factor v. Attitude

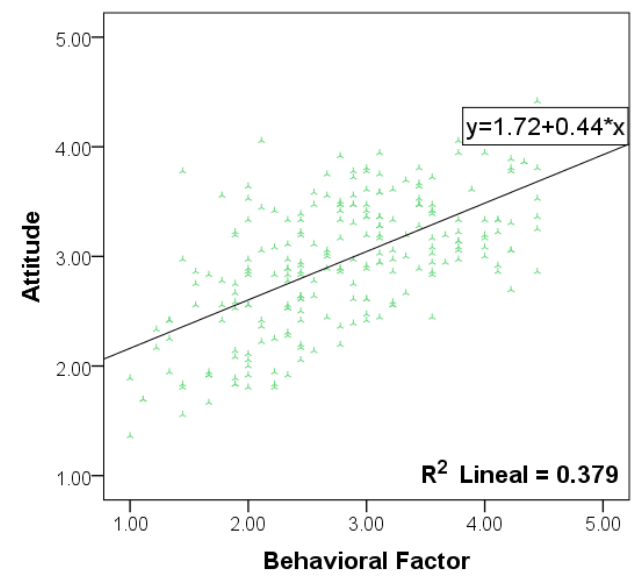

